M. A. Z. Coelho • I. Belo • R. Pinheiro • A. L. Amaral •

M. Mota - J. A. P. Coutinho $\cdot$ E. C. Ferreira

\title{
Effect of hyperbaric stress on yeast morphology: study by automated image analysis
}

Received: 19 February 2004 / Revised: 28 April 2004 / Accepted: 30 April 2004 / Published online: 15 July 2004

(C) Springer-Verlag 2004

\begin{abstract}
The effects of hyperbaric stress on the morphology of Saccharomyces cerevisiae were studied in batch cultures under pressures between $0.1 \mathrm{MPa}$ and $0.6 \mathrm{MPa}$ and different gas compositions (air, oxygen, nitrogen or carbon dioxide), covering aerobic and anaerobic conditions. A method using automatic image analysis for classification of $S$. cerevisiae cells based on their morphology was developed and applied to experimental data. Information on cell size distribution and bud formation throughout the cell cycle is reported. The results show that the effect of pressure on cell activity strongly depends on the nature of the gas used for pressurization. While nitrogen and air to a maximum of $0.6 \mathrm{MPa}$ of pressure were innocuous to yeast, oxygen and carbon dioxide pressure caused cell inactivation, which was confirmed by the reduction of bud cells with time. Moreover, a decrease in the average cell size was found for cells exposed for $7.5 \mathrm{~h}$ to $0.6 \mathrm{MPa} \mathrm{CO}_{2}$.
\end{abstract}

\section{Introduction}

The yeast Saccharomyces cerevisiae is one of the most important microorganisms employed in industry. Growth rate, mutation, and environmental conditions affect yeast size and shape distributions but, in general, the influence

M. A. Z. Coelho $\cdot$ I. Belo $(\bowtie) \cdot$ R. Pinheiro $\cdot$ A. L. Amaral · M. Mota · E. C. Ferreira

Centro de Engenharia Biológica, Universidade do Minho, Campus de Gualtar,

4710-057 Braga, Portugal

e-mail: ibelo@deb.uminho.pt

Tel.: +351-253-604413

Fax: +351-253-678986

M. A. Z. Coelho · J. A. P. Coutinho

CICECO, Departamento de Química, Universidade de Aveiro, Aveiro, Portugal

M. A. Z. Coelho

Departamento de Engenharia Bioquímica, Escola de Química/ UFRJ,

Rio de Janeiro, Brazil of spatial variations in large-scale bioreactors is not considered. Many differences found between laboratory and industrial behavior can be partially explained by different environmental conditions, especially when gas solubility is an important parameter, since it is a function of the local position within the reactor (Onken and Liefke 1989). As a consequence, analysis of pressure effects in cell physiology and morphology must be considered.

Both $\mathrm{O}_{2}$ and $\mathrm{CO}_{2}$ partial pressures are directly involved in yeast metabolism, the former being an essential nutrient for cell respiration whereas $\mathrm{CO}_{2}$ is a product of cellular metabolic activity. Previous work demonstrated that hyperbaric air could be successfully applied to fed-batch cultivation of $S$. cerevisiae, to improve the oxygen transfer rate to aerobic cultures (Belo et al. 2003). However, above certain limits the increased air pressure and the consequent increase in oxygen partial pressure had detrimental effects on yeast cell activity. It was proven that oxygen toxicity, besides total pressure, is the main cause of cell inhibition (Pinheiro et al. 1997, 2002).

The rise in carbon dioxide partial pressure in aerobic cultures has also been studied and detrimental effects on yeast growth reported (Belo et al. 2003). In this latter study, low values of $\mathrm{CO}_{2}$ pressure were investigated and no attempt was made to describe $S$. cerevisiae physiology and morphology under hyperbaric anaerobic conditions. Other authors proved that high-pressure $\mathrm{CO}_{2}$ inhibits yeast fermentation, but the pressure used was unusually high $(7 \mathrm{MPa})$ in traditional bioreactor operation (Thibault et al. 1987).

In this work, batch studies with pure air, oxygen, nitrogen or carbon dioxide were performed, covering aerobic and anaerobic conditions often used in fermentation technology. Besides metabolic analysis of hyperbaric stress on yeast cells, a further insight is made into morphological changes caused by different gases at moderate pressures. Using recent developments in computer image analysis for automatic evaluation of microscopic images, a description of a self-developed image analysis procedure for $S$. cerevisiae morphology evaluation is presented. This technique was applied to study 
morphological cell changes under different operational conditions based on the influence of an increased baric environment. The projected area of cells and number of bud cells were used to evaluate morphological changes. Other authors have used different parameters, such as cell volume, to assess cellular morphology under stress conditions (Marechal and Gervais 1994).

\section{Materials and methods}

Experimental conditions

\section{Yeast strain and medium}

S. cerevisiae ATCC 32167 was used in this work and was preserved at $-80^{\circ} \mathrm{C}$ in $20 \%(\mathrm{v} / \mathrm{v})$ glycerol. From these stock cultures, agar plates $\left(20 \mathrm{~g} \mathrm{l}^{-1}\right.$ agar) were inoculated and colonies from these plates were used as inoculum for batch experiments under hyperbaric conditions. The culture medium comprised $0.4 \mathrm{~g} \mathrm{l}^{-1} \mathrm{MgSO}_{4} \cdot 7 \mathrm{H}_{2} \mathrm{O}$, $2.0 \mathrm{~g} \mathrm{l}^{-1}\left(\mathrm{NH}_{4}\right)_{2} \mathrm{SO}_{4}, 5.0 \mathrm{~g} \mathrm{l}^{-1} \mathrm{KH}_{2} \mathrm{PO}_{4}, 1.0 \mathrm{~g} \mathrm{l}^{-1}$ yeast extract, and $5.0 \mathrm{~g} \mathrm{l}^{-1}$ glucose. The $\mathrm{pH}$ was adjusted to 4.0 prior to autoclaving. Inocula were grown for $15 \mathrm{~h}$ at $30^{\circ} \mathrm{C}$ and $120 \mathrm{rpm}$ in an orbital incubator in a $250-\mathrm{ml}$ shaker flask containing $50 \mathrm{ml}$ medium.

\section{Batch cultivation}

Experiments were carried out in a $600-\mathrm{ml}$ stainless steel reactor (Parr 4563; Parr Instruments, Moline, Ill.) at a temperature of $30^{\circ} \mathrm{C}$ and a stirring rate of $400 \mathrm{rpm}$. Compressed pure gas was continuously sparged into the culture medium at a flow-rate of $11 \mathrm{~min}^{-1}$ (measured at standard conditions of pressure and temperature). The reactor was connected to different bottles containing the pure gases (air, oxygen, $\mathrm{N}_{2}$ or $\mathrm{CO}_{2}$ ). The operating pressure was set by manipulation of the pressure of the inlet gas and the regulatory valve position in the exit gas line. The reactor was equipped with a pressure transducer to monitor total internal pressure. The medium used in pressurized reactor experiments had the same composition as the medium used for inoculum preparation. The initial yeast concentration was $0.2 \mathrm{~g} \mathrm{l}^{-1}$.

\section{Analytical methods}

Cell concentration was estimated through optical density at a wavelength of $620 \mathrm{~nm}$, previously correlated to dry weight determination. Glucose was measured using the 3,5-dinitrosalycilic acid method (Miller 1959). Ethanol was quantified by HPLC (Jasco, Great Dunmow, Essex, UK) with a Chrompack column (Organic acids) and an RI detector (830-PU, Jasco). The eluent was $0.01 \mathrm{~N} \mathrm{H}_{2} \mathrm{SO}_{4}$ at $0.7 \mathrm{ml} \mathrm{min}{ }^{-1}$ at a column temperature of $40^{\circ} \mathrm{C}$.

\section{Image analysis}

Image acquisition was conducted using an optical microscope (Diaphot 300, Nikon) with $400 \times$ magnification coupled with a black and white camera (Sony CCD AVC D5CE) linked to a personal computer by a frame grabber (DT3155, Data Translation, Marlboro, Mass.). The images were focused in such a way as to enhance cell contours (Fig. 1a). The background (an image without cells) was subtracted from the original image to remove irregularities. A median filter $(3 \times 3)$ was used in the resulting image before the binarization step. Afterwards, a step to suppress objects connected to the image border, and a hole-fill procedure (Russ 2002) were performed. Application of morphological operations, such as erosion (to remove small debris) and reconstruction, produced the final binary image (Fig. 1b). These image processing procedures were developed using the Matlab v.6.1 (The Mathworks, Natick, Mass.) package and were fully automated.

Feature extraction and object separation were necessary to classify "mothers" and "daughters" and to determine their frequency in the samples analyzed. Initially, objects were labeled, permitting individual properties (area, equivalent diameter, major axis length, minor axis length and orientation, among others) to be extracted. Assuming that the cell projection onto the image is an ellipse, a parameter called "elongation" (major axis length/minor axis length) was computed according to Pons and Vivier (1998) to discriminate non-bud from bud cells. A typical elongation distribution for cells of $S$. cerevisiae ATCC 32167 is presented in Fig. 2. Based on the effect of different elongation values studied (1.5, 2.0 and 3.0), an
Fig. 1 a Initial image from microscope. b Final image obtained after digital processing

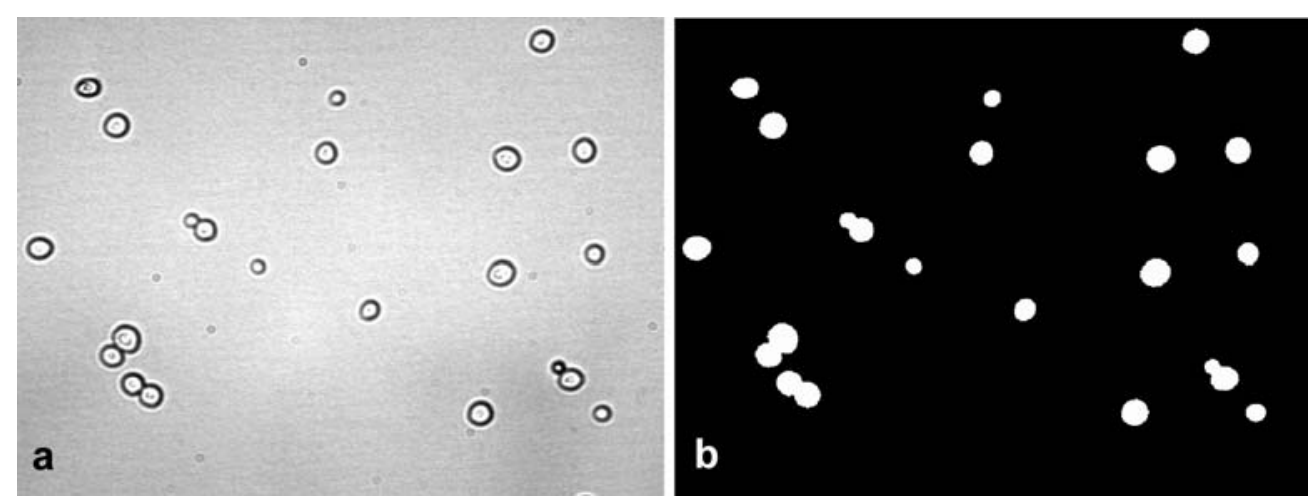


elongation factor value of 1.5 was selected for all the analysis to discriminate buds from single cells.

\section{Results}

Image analysis

\section{Threshold analysis}

The appropriate threshold with which to separate objects from the background is extremely correlated to the image contrast. Measurement of some object properties depends on the threshold value (Vicente et al. 1996). Analysis of cell properties such as number of objects, total area, mean area and number of bud cells with various threshold values was performed. Figure 3 presents such data demonstrating the existence of a threshold range where most properties remain constant (between 0.8 and 0.9), i.e., the results obtained in this range are relatively independent of the threshold employed. A threshold value of 0.85 was chosen to perform all other analysis.

\section{Data consistency}

To check the consistency of the results obtained through automatically calculated parameters, a manual determination of total and bud cells was performed and compared with the results from the image analysis. A total of 100 pictures, corresponding to 2,000 objects, was analyzed. A good correlation was reached for the number of total objects, with the average error being $<5 \%$ for both ranges analyzed herein. For bud cells, a systematic deviation is observed when comparing automatic to manual determinations. This deviation seems to increase when large numbers of bud cells are determined in each image, leading to a correction factor of about 14\% (Fig. 4).

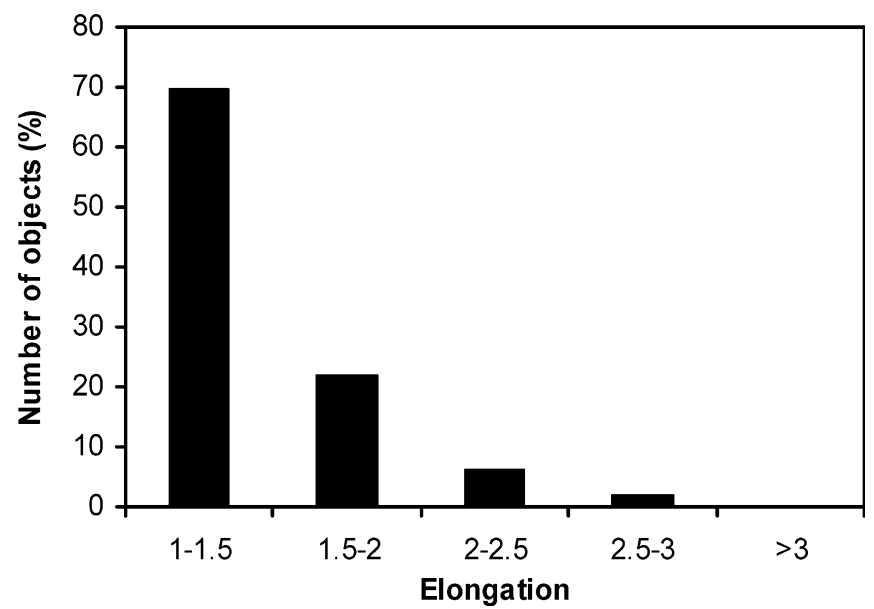

Fig. 2 Typical elongation distribution for Saccharomyces cerevisiae ATCC 32167. The elongation parameter is defined as the ratio between the major axis length and the minor axis length
Hyperbaric effects

Effects on aerobic and anaerobic cell metabolism

To investigate the effects of hyperbaric gases on the metabolism of $S$. cerevisiae, batch cultures were carried out in a hyperbaric reactor at different conditions of total pressure and pressurizing gas, keeping other operating conditions unchanged. The effect on cell growth of pressure up to $0.6 \mathrm{MPa}$ strongly depends on the nature of the gas used for pressurization, as demonstrated by the results presented in Table 1. An increase in air pressure to $0.6 \mathrm{MPa}$, which corresponds to $0.12 \mathrm{MPa}$ oxygen partial pressure, leads to a considerable increase $(52 \%)$ in cell growth rate, showing results similar to those described by Belo et al. (2003) for fed-batch cultivation. Moreover, yeast cells metabolized all the substrate initially present in the culture medium, leading to common cell and ethanol mass yields of batch cultures of $S$. cerevisiae. On the other hand, the influence of an oxidative environment determined by a pure oxygen atmosphere of $0.3 \mathrm{MPa}$ or above, drives the cell response in the opposite direction. Below $0.3 \mathrm{MPa}$ pure oxygen, substrate uptake was greatly reduced. This inhibition was reflected in the low mass yields obtained. Furthermore, an increase in oxygen pressure from $0.3 \mathrm{MPa}$ to $0.5 \mathrm{MPa}$ induced a drastic decrease $(90 \%)$ in cell growth rate. Due to cell inactivation, no ethanol was produced, and glucose remained in the medium at a concentration near to the initial value.

Under anaerobic conditions, no significant differences were found in cell growth rate at $0.1 \mathrm{MPa}$ and $0.6 \mathrm{MPa}$ nitrogen. The $\mathrm{N}_{2}$ pressure increase to $0.6 \mathrm{MPa}$ stimulated the fermentative activity of the cells, since an increase in ethanol yield and a decrease in the cell mass per ethanol mass produced were found. On the contrary, the increase in $\mathrm{CO}_{2}$ pressure within this range reduced cell growth by $82 \%$, a behavior under anaerobic conditions similar to that described for oxygen.

Ethanol production was also affected by the carbon dioxide pressure increase. In fact, $0.6 \mathrm{MPa} \mathrm{CO}_{2}$ caused a 3 -fold reduction in ethanol yield $\left(0.17 \mathrm{~g} \mathrm{~g}^{-1}\right)$ compared to that obtained for $\mathrm{N}_{2}\left(0.52 \mathrm{~g} \mathrm{~g}^{-1}\right)$ at the same pressure. However, cell mass production is more affected by hyperbaric $\mathrm{CO}_{2}$ than ethanol production, since a decrease

Table 1 Effect of gas pressure on yields of cell mass per mass of glucose consumed, $Y_{X / S}$, ethanol mass per glucose, $Y_{E / S}$, cell mass per mass of ethanol produced, $Y_{X / E}$, and specific cell growth rate at the exponential phase of growth, $\mu$, for batch cultivation of Saccharomyces cerevisiae. Data are means of two independent replicates

\begin{tabular}{|c|c|c|c|c|c|c|c|c|}
\hline \multirow{2}{*}{$\begin{array}{l}\text { Gas } \\
\text { Pressure }(\mathrm{MPa})\end{array}$} & \multicolumn{2}{|l|}{ Air } & \multicolumn{2}{|l|}{$\mathrm{O}_{2}$} & \multicolumn{2}{|l|}{$\mathrm{N}_{2}$} & \multicolumn{2}{|l|}{$\mathrm{CO}_{2}$} \\
\hline & 0.1 & 0.6 & 0.3 & & 0.1 & .6 & 0.1 & 0.6 \\
\hline & 0.2 & 0.2 & 0. & 0 & 0.16 & 0.19 & 0.15 & 0.0 \\
\hline$Y_{E / S}\left(\mathrm{~g} \mathrm{~g}^{-1}\right)$ & 0.41 & 0.35 & 0.04 & 0.00 & 0.36 & 0.52 & 0.30 & 0.17 \\
\hline$Y_{X / E}\left(\mathrm{~g} \mathrm{~g}^{-1}\right)$ & 0.71 & 0.71 & 3.5 & - & 0.44 & 0.36 & 0.50 & 0.29 \\
\hline$\mu\left(\mathrm{h}^{-1}\right)$ & 0.25 & 0.37 & 0.24 & 0.02 & 0.23 & 0.28 & 0.23 & 0.04 \\
\hline
\end{tabular}


Fig. 3a-d Threshold range analysis. a Number of objects, $\mathbf{b}$ mean area, c total area, $\mathbf{d}$ number of bud cells for various threshold values

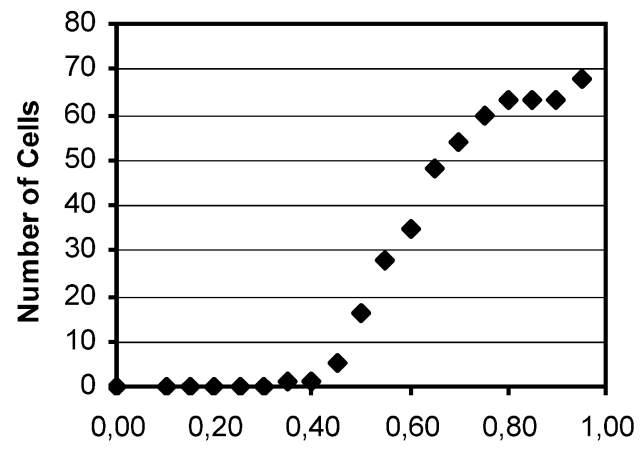

(a)

Threshold

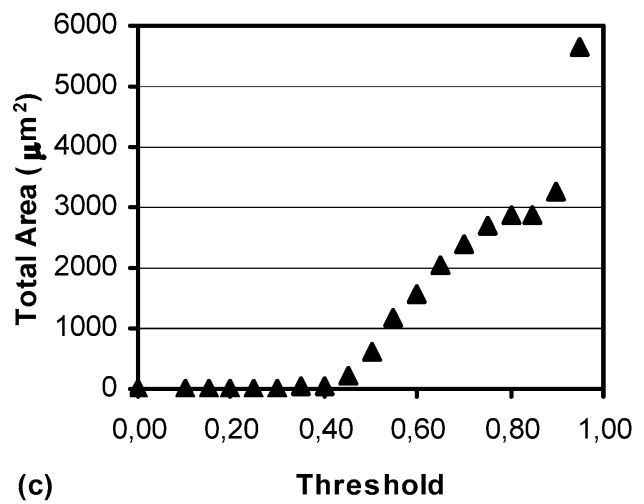

(b)
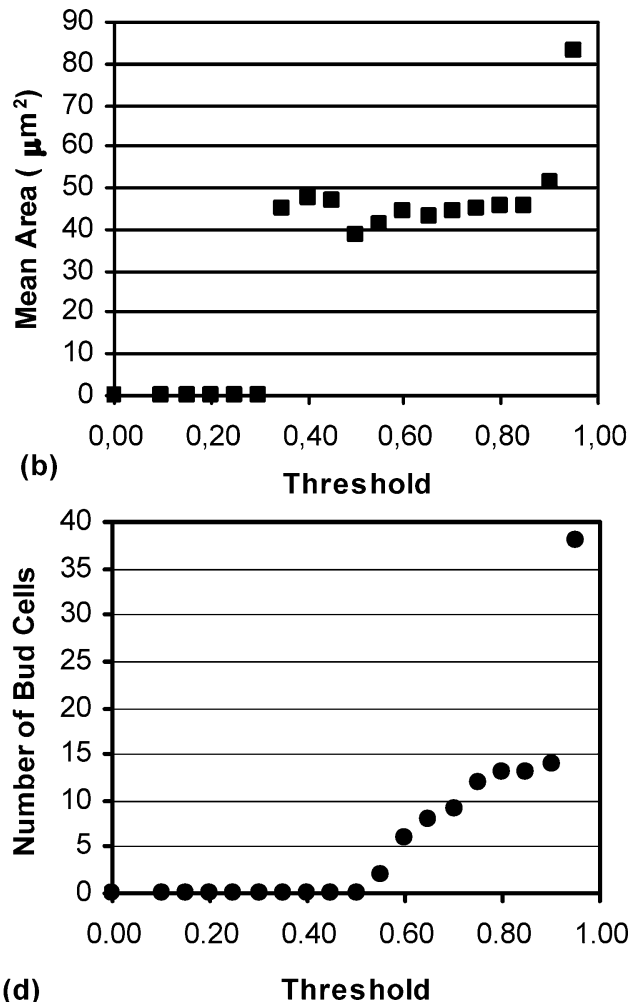

in the cell mass per ethanol mass yield $\left(Y_{X / E}\right)$ was verified for the $\mathrm{CO}_{2}$ pressure rise.

\section{Effects on cell division}

The inhibition of cell activity observed with increasing oxygen and carbon dioxide pressure was confirmed by the reduction in the percentage of bud cells with time (Fig. 5). The percentage of bud cells increases soon after inocula- tion, following the usual growth processes, and reaches its maximum value at the late exponential phase of growth. The decay observed under some conditions after $4 \mathrm{~h}$ of cultivation can be explained by the different glucose consumption rates obtained (data not shown). The low number of bud cells observed in the experiments with $\mathrm{CO}_{2}$ and $\mathrm{O}_{2}$ at high pressures indicates that these hyperbaric gases repress cell division.
Fig. 4 Data consistency for automatic bud cell discrimination

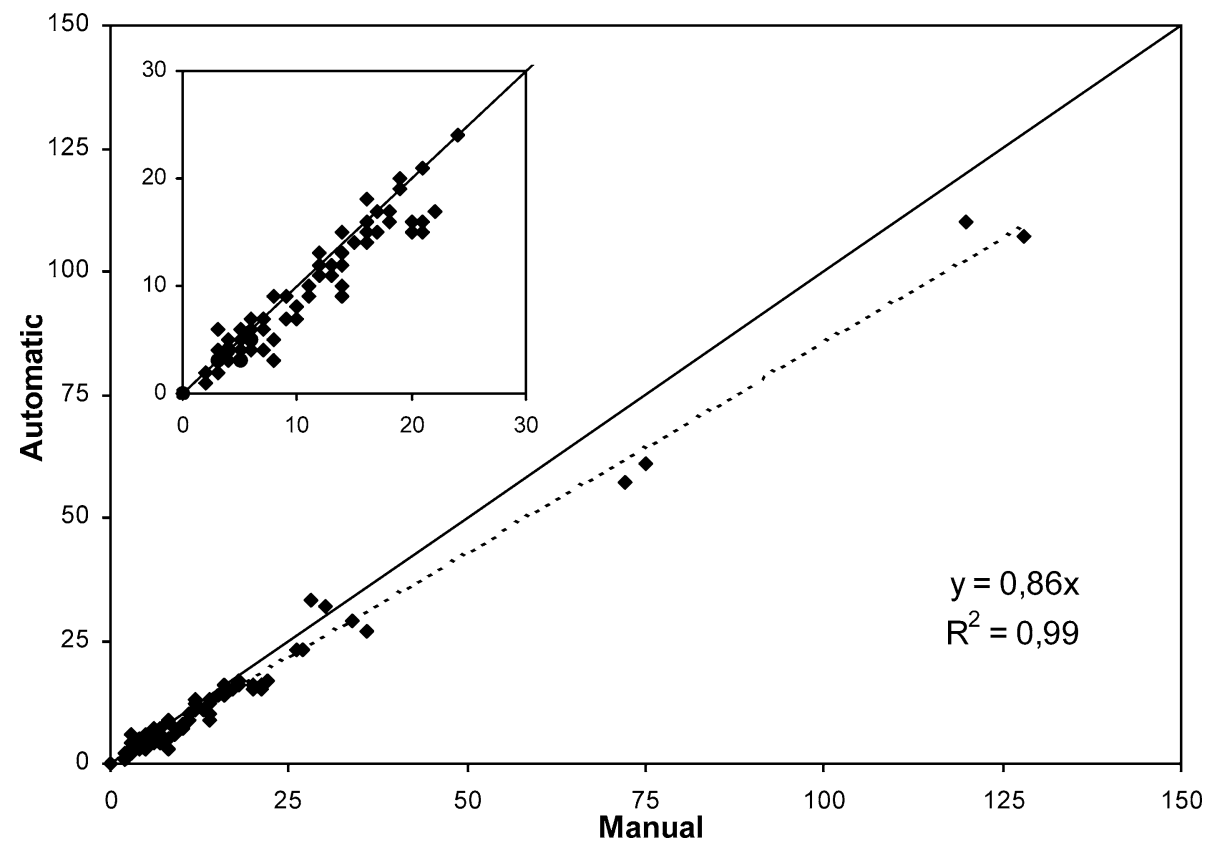



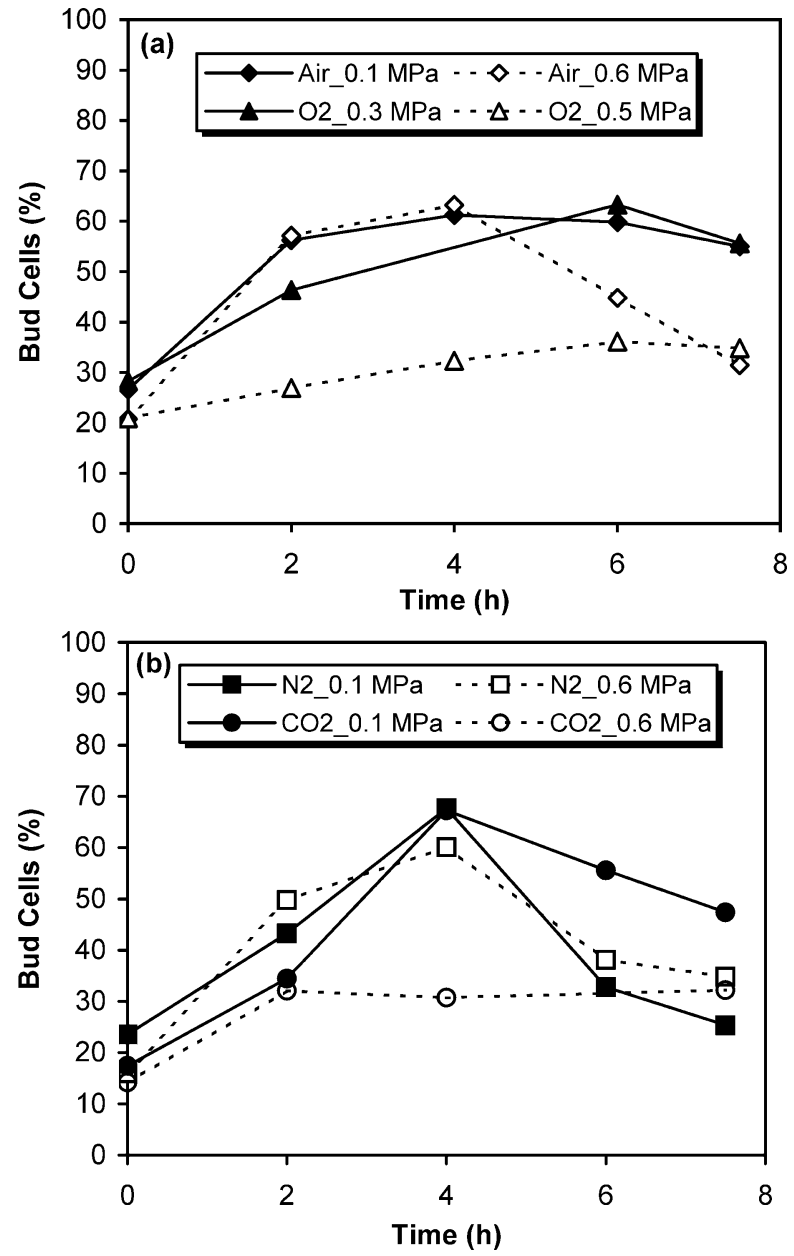

Fig. 5 Bud cell percentage over batch time for $\mathbf{a}$ aerobic and $\mathbf{b}$ anaerobic experiments

\section{Effects on cell morphology}

An image-processing tool accomplished analysis of cell morphology under the different experimental conditions used. The mean area of the initial culture cells in all experiments was determined as $33 \pm 12 \mu \mathrm{m}^{2}$. The cell size distributions obtained present a Gaussian type profile (Fig. 6). The Gaussian parameters determined for each cell size distribution after $7.5 \mathrm{~h}$ of cultivation are reported in Table 2. An increase in the cell size distribution, with respect to its initial values, was obtained for almost all the gases and pressures tested, except in the case where $0.6 \mathrm{MPa} \mathrm{CO}_{2}$ was used.

Table 2 Gaussian parameters of cell size distribution for the final cultures. $S D$ Standard deviation, $n$ total number of cells

\begin{tabular}{|c|c|c|c|c|c|c|c|c|}
\hline \multirow{2}{*}{$\begin{array}{l}\text { Gas } \\
\text { Pressure (MPa) }\end{array}$} & \multicolumn{2}{|l|}{ Air } & \multicolumn{2}{|l|}{$\mathrm{O}_{2}$} & \multicolumn{2}{|l|}{$\mathrm{N}_{2}$} & \multicolumn{2}{|l|}{$\mathrm{CO}_{2}$} \\
\hline & 0.1 & 0.6 & 0.3 & 0.5 & 0.1 & 0.6 & 0.1 & 0.6 \\
\hline$A($ & 6 & 41 & 51.8 & 47.1 & 38.1 & 41.1 & 44.9 & 28.1 \\
\hline $\mathrm{SD}$ & 15.4 & 14.9 & 23.4 & 12.9 & 12.8 & 15.2 & 15.2 & 10.3 \\
\hline$n$ & 128 & 207 & 247 & 74 & 238 & 306 & 149 & 242 \\
\hline
\end{tabular}

${ }^{\text {a Average area }}$

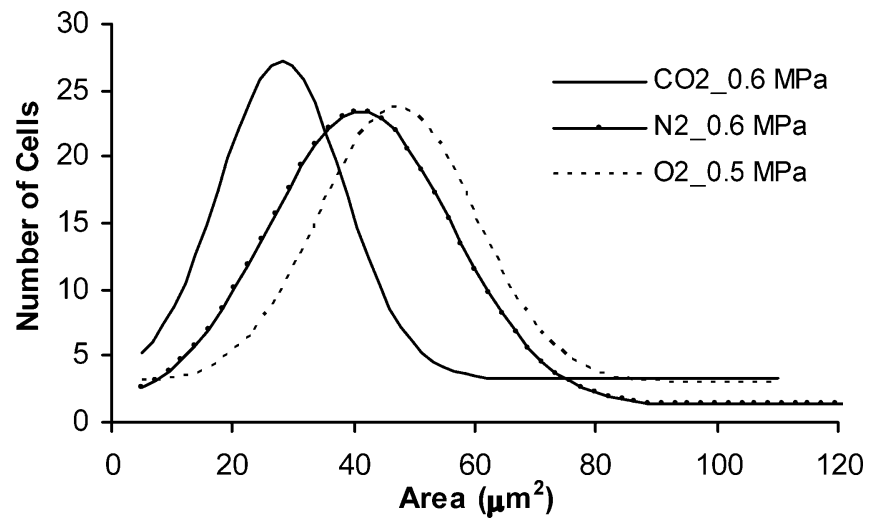

Fig. 6 Gaussian curve fit to cell size distribution for yeast cells grown for $7.5 \mathrm{~h}$ at $0.5 \mathrm{MPa} \mathrm{O}_{2}, 0.6 \mathrm{MPa} \mathrm{CO}_{2}$ and $0.6 \mathrm{MPa} \mathrm{N}_{2}$

\section{Discussion}

The results described above for different gases and pressures clearly show that the nature of the gas is crucial for the pressure effect on yeast activity. It can be stated that an increase of pressure to a maximum of $0.6 \mathrm{MPa}$ has no detrimental metabolic effects on the cells whenever nitrogen or air is applied. These results are in accordance with previous work (Belo et al. 2003), where no cell activity inhibition was found up to $1 \mathrm{MPa}$ air in fed-batch yeast cultivation. Moreover, in the present work, the air pressure increase stimulated cell growth due to higher oxygen availability in the medium. Several authors have shown that use of increased air or oxygen pressure is an efficient means of oxygenation improvement in various microbial cell cultures (Yang and Wang 1992; Wendlandt et al. 1993; Lee et al. 1997; Belo and Mota 1998; Pinheiro et al. 2003).

However, there are limits for the air or oxygen pressure increase depending on the microorganism and strain. For inhibition of batch growth of $S$. cerevisiae, Abel et al. (1994) reported lower values of oxygen partial pressure than the values found herein. Under aerobic conditions, it can be assumed that it is oxygen toxicity, and not the total pressure itself, that is the major cause of cell damage, since drastic cell inhibition was found under pure oxygen atmosphere at $0.5 \mathrm{MPa}$. This effect is explained in the literature by the oxidative stress imposed by $\mathrm{O}_{2}$ overprovision (Pinheiro et al. 2002; Moradas-Ferreira et al. 1996).

Under anaerobic conditions, different effects were also obtained for $\mathrm{N}_{2}$ and $\mathrm{CO}_{2}$ environments. An increase in $\mathrm{N}_{2}$ pressure to $0.6 \mathrm{MPa}$ did not affect cell growth, and slightly enhanced ethanol production. Thus, as far as fermentation process are concerned, the size of the reactor and local variations in pressure due to hydrostatic liquid pressure (to a maximum of $0.6 \mathrm{MPa}$ ), should not interfere with process performance if nitrogen is used as sparging gas.

On the other hand, a $\mathrm{CO}_{2}$ environment of $0.6 \mathrm{MPa}$ inhibited the fermentation process. Thibault et al. (1987) reported inhibition of ethanol production under highpressure conditions, and stronger inhibition by $\mathrm{CO}_{2}$ than by $\mathrm{N}_{2}$ was found. In fact, several authors proposed high- 
pressure $\mathrm{CO}_{2}$ as an effective means of cell inactivation (Shimoda et al. 2001; Spilimbergo et al. 2002).

The morphology of the cells seems to be intimately correlated with their physiological state. Thus, in addition to metabolic aspects, other morphological parameters were analyzed for cells cultivated under different baric conditions. Considering evaluation of morphology, an automatic image processing methodology for yeast morphology analysis was described, using an elongation factor as a discriminatory parameter. An average elongation factor of 1.5 for $S$. cerevisiae ATCC 32167 was used to discriminate bud cells from single cells. Other authors (Pons and Vivier 1998) also determined an average value for the elongation factor of 1.5 for single cells, which encompasses nonbudding and also budding mother cells whose bud is not large enough to create a second sub-element.

This methodology enables automated analysis of the effect of stressful environmental conditions on cell division. Since no significant increase in the percentage of bud cells over time was obtained for $\mathrm{O}_{2}$ and $\mathrm{CO}_{2}$ at high pressure, it can be stated that these conditions lead to inhibition of cell division.

Moreover, an influence of the glucose consumption rate on the percentage of bud cells was detected. Experimental conditions with high substrate consumption rates led to a decrease in bud cell percentage: $63 \%$ for $\mathrm{N}_{2}$ at $0.6 \mathrm{MPa}$, $50 \%$ for air at $0.6 \mathrm{MPa}, 42 \%$ for $\mathrm{N}_{2}$ at $0.1 \mathrm{MPa}$, and $30 \%$ for $\mathrm{CO}_{2}$ at $0.1 \mathrm{MPa}$. Under these conditions, only $10-20 \%$ of the initial carbon source remains in the medium after $4 \mathrm{~h}$ of batch experiment. Moreover, faster cell growth at high pressures of $\mathrm{N}_{2}$ and air led to a faster attainment of the stationary phase of growth, with concomitant retardation of cell division. Under other conditions $\left(\mathrm{CO}_{2}\right.$ and $\mathrm{O}_{2}$ at high pressure), the bud cell percentage remained constant until the end of the process, as the sugar concentration was $>50 \%$ of its initial value at that moment. This also indicates that cells under these hyperbaric gases were kept in the lag phase.

In spite of the similarity between the effects of highpressure oxygen and carbon dioxide on bud formation, differences in cell morphology were detected. Over batch time, the different pressure conditions and the nature of the gas used did not significantly affect average cell size. For almost all the experiments an increase in cell size with time was obtained, which is in accordance with cell growth retardation at the stationary phase of growth.

Nevertheless, a cell size decrease was found in the case of the final culture exposed to $0.6 \mathrm{MPa} \mathrm{CO}_{2}$. This effect could be explained by cell growth inhibition in combination with cell membrane damage. $\mathrm{CO}_{2}$ compression and decompression inside the cell may be responsible for the cell membrane leakage, which, in turn, leads to the loss of intracellular biomolecules of low molecular weight and the consequent reduced cell size. Identical effects of hydrostatic pressure and of high-pressure $\mathrm{CO}_{2}$ were reported by Shimada et al. (1993) and Nakamura et al. (1994). Oxidative stress can also damage cellular membranes through lipidic peroxidation, but this effect was not detected in this work, probably due to the short period of hyperbaric cell exposure.

\section{Conclusions}

The assessment of metabolic and morphological behavior of $S$. cerevisiae under different pressures $(0.1-0.6 \mathrm{MPa})$ and gas composition (air, oxygen, nitrogen and carbon dioxide) is described. The results reported show that the nature of the gas is crucial for the pressure effect on yeast activity since, under aerobic conditions, oxygen toxicity and not the total pressure itself, is the major cause of cell damage. Moreover, the influence of hyperbaric $\mathrm{N}_{2}$ on the fermentation process is not as severe as that of $\mathrm{CO}_{2}$. The results obtained allow the conclusion that, as far as biological aspects are concerned, total pressure is an important parameter to take into account in bioreactor design and operation, since it affects oxygen and carbon dioxide partial pressures. The similarity of cell inactivation effects due to these hyperbaric gases open new perspectives of selecting modified atmospheres for biomaterial preservation.

In the present work, an automated image analysis procedure allowing discrimination between buds and single cells, as well as determination of cell size distribution under different experimental conditions, was developed. The main advantage of using such a procedure is that the large number of objects analyzed leads to more representative data analysis. This methodology led to the conclusion that cell division is strongly affected by $0.5 \mathrm{MPa} \mathrm{O}_{2}$ and $0.6 \mathrm{MPa} \mathrm{CO}_{2}$ pressures. On the other hand, cultures exposed to $0.6 \mathrm{MPa} \mathrm{CO}_{2}$ exhibited an average decrease in cell size. Thus, the measurement of bud cells is a better method to identify cell activity inhibition than cell size determination. The methodology herein proposed could be very useful in the physiological state assessment and cell division analyses of yeast cell cultures used in industrial processes.

Acknowledgements M.A.Z. Coelho is grateful for the scholarship and financial support given by CAPES and CNPq (Brazil) for this work development in Portugal. A.L. Amaral was supported by PRAXIS XXI/BD/20325/99 grant and R. Pinheiro was also supported by PRAXIS XXI/BD/11498/97 grant of Fundação para a Ciência e Tecnologia (Portugal).

\section{References}

Abel C, Hübner U, Schügerl K (1994) Transient behaviour of baker's yeast during enforced periodical variation of dissolved oxygen concentration. J Biotechnol 32:45-57

Belo I, Mota M (1998) Batch and fed-batch cultures of E. coli TB1 at different oxygen transfer rates. Effect of stirring and oxygen partial pressures on cell growth and cytochrome b5 production. Bioprocess Eng 18:451-455

Belo I, Pinheiro R, Mota M (2003) Fed-batch cultivation of Saccharomyces cerevisiae in a hyperbaric bioreactor. Biotechnol Prog 19:665-671 
Lee J, Lee SY, Park S (1997) Fed-batch culture of Escherichia coli $\mathrm{W}$ by exponential feeding of sucrose as a carbon source. Biotechnol Tech 11:59-62

Marechal PA, Gervais P (1994) Yeast viability related to water potential variation-influence of the transient phase. Appl Microbiol Biotechnol 42:617-622

Miller GE (1959) Use of dinitrosalicylic acid reagent for determination of reducing sugar. Anal Chem 31:426-428

Moradas-Ferreira P, Costa V, Piper P, Mager W (1996) The molecular defenses against reactive oxygen species in yeast. Mol Microbiol 19:651-658

Nakamura K, Enomoto A, Fukushima H, Nagai K, Hakoda M (1994) Disruption of microbial cells by the flash discharge of high-pressure carbon dioxide. Biosci Biotechnol Biochem 58:1297-1301

Onken U, Liefke E (1989) Effect of total and partial pressure (oxygen and carbon dioxide) on aerobic microbial processes. In: Fiechter A (ed) Advances in biochemical engineering/ biotechnology. Springer, Berlin Heidelberg New York, pp 137169

Pinheiro R, Belo I, Mota M (1997) Physiological behavior of Saccharomyces cerevisiae under increased air and oxygen pressures. Biotechnol Lett 19:703-708

Pinheiro R, Belo I, Mota M (2002) Oxidative stress response of Kluyveromyces marxianus to hydrogen peroxide, paraquat and pressure. Appl Microbiol Biotechnol 58:842-847

Pinheiro R, Belo I, Mota M (2003) Growth and $\beta$-galactosidase activity in cultures of Kluyveromyces marxianus under increased air pressure. Lett Appl Microbiol 37:438-442
Pons MN, Vivier H (1998) Morphometry of yeast. In: Wilkinson MHF, Schut F (eds) Digital image analysis of microbes: imaging, morphometry, fluorometry and motility techniques and applications. Wiley, New York, pp 199-224

Russ CR (2002) The image processing handbook, 4th edn. CRC, Boca Raton

Shimada S, Andou M, Naito N, Yamada N, Osumi M, Hayashi R (1993) Effects of hydrostatic pressure on the ultrastructure and leakage of internal substances in the yeast Saccharomyces cerevisiae. Appl Microbiol Biotechnol 40:123-131

Shimoda M, Cocunubo-Castellanos J, Kago H, Miyake M, Osajima Y, Hayakawa I (2001) The influence of dissolved $\mathrm{CO}_{2}$ concentration on the death kinetics of Saccharomyces cerevisiae. J Appl Microbiol 91:306-311

Spilimbergo S, Elvassore N, Bertucco A (2002) Microbial inactivation by high-pressure. J Supercrit Fluids 22:55-63

Thibault J, LeDuy A, Côté F (1987) Production of ethanol by Saccharomyces cerevisiae under high-pressure conditions. Biotechnol Bioeng 30:74-80

Vicente A, Meinders JM, Teixeira JA (1996) Sizing and counting of Saccharomyces cerevisiae floc populations by image analysis, using an automatically calculated threshold. Biotechnol Bioeng 51:673-678

Wendlandt KD, Jechorek M, Brühl E (1993) The influence of pressure on the growth of methanotrophic bacteria. Acta Biotechnol 13:11-115

Yang JD, Wang NS (1992) Oxygen mass transfer enhancement via fermentor headspace pressurization. Biotechnol Prog 8:244 251 